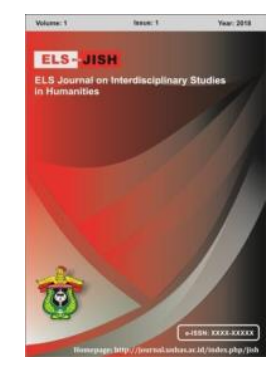

ELS-JISH

ELS Journal on Interdisciplinary Studies on Humanities

Volume 3 Issue 1, 2020

ISSN (print) : 2621-0843

ISSN (online) : 2621-0835

Homepage : http://journal.unhas.ac.id/index.php/jish

\title{
Native English Teacher's Politeness Realizations in EFL Classroom Interaction
}

\author{
Wisma Wijayanti ${ }^{1}$, Agus Wijayanto ${ }^{2}$, Sri Marmanto ${ }^{3}$ \\ 1wismawijaya23@gmail.com
}

\begin{abstract}
The realizations of politeness need to be implemented in the process of teaching and learning in the class, especially in English language classroom context. Applying appropriate politeness strategy in talking to the students is very important to create effective teaching and learning process. This study examines politeness strategies used by the native English teacher. It aims to identify the use of politeness strategies realized by the native English teacher in classroom interaction. This research was qualitative research method. The participant of the research was one native English teacher who taught EFL students in a university in Indonesia. The data were obtained through the class observation. Those data then were analyzed by using politeness theory proposed by Brown and Levinson (1987). The result revealed that all politeness strategies suggested by Brown and Levinson (1987) were applied by the teacher in delivering his speech to the students, such as bald on record, positive politeness, negative politeness, and off record. Negative politeness became the most dominant politeness strategy performed by the native English teacher while the least one was off record. These four strategies were mostly employed by the teacher in order to remind the students, give them commands (task-oriented), praise the students, request the students to do something, make the class more interesting, and motivate the students.
\end{abstract}

Keywords: Politeness strategies, Language teaching, Teacher's talk, Speech acts.

How to cite: Wijayanti, et al. (2020). Native English Teacher's Politeness Realizations in EFL Classroom Interaction. ELS Journal on Interdisciplinary Studies in Humanities, 3(1), 31-40. DOI: http://dx.doi.org/10.34050/els-jish.v3i1.9524

\section{Introduction}

Language classroom plays an important role to manage the teaching and learning process. It means that language used by the teacher and the students determines the success of teaching and learning process in the class. Therefore, in order to achieve the goal of language teaching, there must be mutual relationship between the teacher and the students, such as a good communication among them in giving and receiving information.

The basic aspect used to create a good communication is called politeness. As stated by Lakoff (1990) that politeness is a system of interpersonal relations designed to facilitate interaction by minimizing the potential for conflict and confrontation inherent in all human interchange. In

${ }^{1,2,3}$ English Education Department, Universitas Sebelas Maret, Surakarta, Indonesia. 
other words, politeness can be used to avoid conflict, so it can be assumed that politeness includes the speaker's intention not to offend the hearer in social interactions, like communication (Lakoff, 1990).

Politeness within the concept of face based on Brown and Levinson (1987) is a form of language behavior that allows the maintenance of communication occurs among the participants by considering the 'face' as a kind of illustration or reputation of self-image. Brown and Levinson (1987) provided two terms named Face Threatening Act (FTA) and Face Saving Act (FSA). A Face Threatening Act (FTA) is an act that happens when the speaker says something representing a threat to another individual's expectations regarding self-image. Meanwhile, it is called as a Face Saving Act if it is given the possibility that some action might be interpreted as a threat to another's face, but the speaker can say something to minimize the possible threat. In this case, the speakers should be careful in using FTAs, bacause it can damage the hearer's face (self-image). Nevertheless, the speaker can minimize the possible threat to the hearer's face in performing FTAs by applying four types of politeness strategies proposed by Brown and Levinson (1987), namely bald onrecord, positive politeness, negative politeness, and off-record.

The realization of politeness strategies should be applied in classroom interaction. According to Kasper and Rose (2001), politeness regulates communicative action and interaction throughout communities, eventhough what counts as polite and how this principle is implemented in the context varies across cultures. In classroom interaction, politeness strategy conveyed by the teacher and the students can create a good environment among them, such as a comfortable atmosphere in the class. This kind of situation leads the teaching and learning process run well, so that the students will be able to receive the knowledge delivered by the teacher easily.

Politeness is important to be implemented in the process of teaching and learning in the class, especially in language teaching class. Being polite in the class is very important to create effective teaching and learning process. In recent years, politeness becomes one important issue in education. It seems that the students including the college's students tend to lose their politeness due to the lack of pragmatic knowledge. Thus, the teacher plays an important role to educate the students not only provide the teaching materials but also share the moral values. Teacher's language can shape how students see themselves. Hence, the teacher's language also influences the students' language and behavior. The teacher becomes the model in the class and the students will adjust the way the teacher teaches them, so that the teacher is expected to give a positive impact to the students' behavior through the verbal and nonverbal communication.

In teaching-learning process, the teachers are supposed to apply politeness strategies in their communication. By using appropriate politeness strategy in talking to the students, it can encourage their self-esteem. Futher, it enables the students to save their face, because politeness strategy can be used to minimize the degree of imposition caused by the speaker's utterances (Brown and Levinson, 1987). In addition, politeness can create a good classroom interaction that leads the students to improve their abilities either in 
academic field or non-academic one. In contrast, if the teacher talks to the students in the less polite way, it will make the students feel uncomfortable even they will be ignorant and afraid to respond the teacher's request. Not only the teacher, but the students should also behave and speak politely to their teachers in order to give them respect and avoid offending their feelings. Therefore, the aspect of politeness is meaningful to be used in classroom interaction in order to create effective communication and harmony atmosphere among the teacher and the students.

Previous studies on the realization of politeness strategies in classroom interaction, such as in Peng et al., (2014); Manik and Hutagaol (2015); Agustina and Cahyono (2016); Djatmika et al., (2016); Elisdawati et al., (2018); and Nashruddin et al., (2018) merely investigated the aspects of politeness used by the non-native English teachers. Those related studies reveal that many studies have been conducted in the field of politeness theory in which they merely investigated politeness aspects used by the participants who shared the same culture. However, they still have not examined the realizations of politeness performed by the participants who come from the different culture. Therefore, to fill the gap of research, the present study provides a different insight which is conducted by the different participants in the different context in which the teacher who becomes the participant of this research is an American-English (native) teacher and the students are EFL learners from Indonesia who take English Literature as their major. Finally, the researcher is interested to examine the realizations of politeness performed by an American-English teacher in EFL classroom interaction. Therefore, this study aims to identify the use of politeness strategies realized by the native English teacher in EFL classroom interaction.

\section{Method}

This research was qualitative research method. Qualitative method is an approach that begins with assumptions, a worldview, the possible use of individual or group related to a social or human problem (Creswell, 2007). Qualitative research consists of some characteristics, such as natural setting, participants' meanings, emergent design, theoretical lens, interpretive inquiry, and holistic account (Creswell, 2007: 37). Some characteristics above indicated that this research was involved to qualitative approach in which this study explored politeness realizations conducted in a classroom interaction (natural setting) and the researcher was the one who actually gather the information (researcher as key instrument) through observing behavior and interviewing participant (multiple sources of data).

The participant of the research consisted of an American-English (native) teacher who taught EFL students in a speaking class. There were 31 students in his class in which the students came from English Department major of a university in Indonesia. The data were collected through non-participant observation and also interview. The whole activities of teaching and learning process in the class were recorded and then transcribed in order to make it easy in selecting the data. Then, the data were analyzed by using qualitative data analysis proposed by Miles, Huberman, and Saldana (2014) consisting of 
three flow steps of analysis, such as data condensation, data display, and conclusion drawing/verification.

\section{Finding and Discussion}

This research deals with the analysis of politeness strategies realized by the native English teacher in teaching EFL students based on Brown and Levinson's politeness theory (1987). According to the theory, there are four types of politeness strategies, namely bald on record, positive politeness, negative politeness, and off-record. Here are the findings of the research showing the frequency of politeness strategy conveyed by the native English teacher in the class:

Table 1 . The frequency of politeness strategy usage by the teacher

\begin{tabular}{lc}
\multicolumn{1}{c}{ Politeness Strategies } & Frequency \\
\hline Bald on Record & 17 \\
Positive Politeness & 36 \\
Negative Politeness & 49 \\
Off-Record & 6 \\
\multicolumn{1}{c}{ Total } & 108 \\
\hline
\end{tabular}

Table 1 reports that there were totally 108 utterances containing politeness strategies applied by the native English teacher in his talk to the students in the class. The table also indicates that all politeness strategies proposed by Brown and Levinson (1987) were realized by the teacher in delivering his speech. He mostly used negative politeness strategies whereas he infrequently used off-record strategies when talking to the students in the class.

\subsection{Bald on Record}

Bald on record usage intends to comply the cooperative principle in conversation suggested by Grice (1975). It is employed without any reducing imposition, especially when the speaker is in certain situations (e.g. urgent situations), hence the utterances considered polite do not need to be used anymore in this context. According to Brown and Levinson (1987), bald on record is conveyed by the speaker when he wants to do the face threatening acts (FTAs) with maximum efficiency more than he wants to satisfy the hearer's face. It means that the speaker in some situations prefers to deliver his utterances effectively rather than please the hearer's face.

The use of bald on record strategy in this research was mainly realized by the native English teacher in order to remind (warn) the students and also give commands (intructions) related to the task-oriented. Bald on record strategy is usually characterized by the use of direct imperatives, for examples:
a. "Use bahasa English!"
b. "Tasya, let her read herself!"
c. "Take a ballpoint and just review with your friend all the things he did!"
d. "Be respectful!"
e. "Clap!"
f. "Febrian, tell us about number 16!"
g. "Take a look at the question provided!" 
h. "Be creative!"

The first sentence (a) was uttered by the teacher when he found his student used bahasa Indonesia during the class time. Bald on record strategy in imperative sentence "use bahasa English" was used by the teacher to remind the student use bahasa English when they were at the class. The third sentence (c) happened when the students watched a movie of Mr. Bean. The utterance "take a ballpoint and just review with your friend all the things he did" was expressed by the teacher in order to give them command or instruction (taskoriented), so that they rushed to review the movie before it ended. The fourth sentence (d) occured when a group of students presented the material in front of the class while other students didn't pay attention to the group even they made noise. The imperative form "be respectful" was said by the teacher in the intention to warn the students so they could give their respect to the students who were doing the presentation in front of the class and pay more attention to them.

Since bald on record strategy was expressed directly, it resulted clear meanings, so the students would be easy to understand what the teacher talked to them. As stated by Djatmika et al., (2016) that clear and direct utterances could encourage the students' self esteem. Further, the native English teacher in this research mostly used bald on record when somethings needed to be responded quickly, such as giving instruction or task-oriented and sharing important information. It was in line with Elisdawati et al., (2018) who outlined that the teacher often used bald on record strategy when efficiency was necessary (task-oriented) and also information needed to be shared quickly. Although bald on record risked to damage the hearer's self-image, it could make the students be aware toward their faults so that they would evaluate themselves. In addition, bald on record usage realized by the native English teacher was acceptable in his class due to the authority owned by the teacher over the students.

\subsection{Positive Politeness}

Positive politeness is oriented to the hearer's positive face. It means that the hearer has a face to be appreciated. Positive politeness strategy in this research was frequently conveyed by the native English teacher to give the students compliment, make the class more interesting, and encourage the students' motivation. This strategy could be used to create a good relationship between the teacher and the students through the expressions, for instances:

a. "Alright, good!"

b. "Okay... excellent!"

c. "Good job!"

d. "Let's talk about the next one!"

e. "I know you can do it, so look at audience's eye."

f. "It is pretty easy."

g. "Let's give applause!"

h. "And the last one... me."

i. "If I tell you what it is you would say "oh, really! Its function is a hot water bag." 
The first sentence (a) was expressed by the teacher so long as the students could answer the questions correctly, so he gave them compliment by saying "Alright, good!". As well as with the simple sentences in (b) "okay... excellent!" and (c) "good job!" also indicated a compliment given by the teacher to the students when they did good things. Other than compliment, the optimistic expression also showed the use of politeness strategy, such as in the sentence (e) "I know you can do it, so look at audience's eye" that happened when the students had a presentation on how make some strange meals in front of the class. However, they couldn't engage the audiences well when they presented. Therefore, the teacher evaluated their lack and also motivated them by saying that they could engange the audiences well, so they should look at the audiences' eyes. The utterance "I know you can do it" could make the students confident that they could present in the better way. As outlined by Peng et al., (2014) that in any culture where social face or individual face was of great significance, praises and compliments played a vital important in encouraging interpersonal relationships. The way teachers compliment the students influenced on how successful students perceive themselves (Peng et al., 2014).

Another sentence uttered by applying positive politeness strategy was in sentence (d) "let's talk about the next one!" in which this sentence was employed by the teacher in order to motivate the students so that they had enthusiasm to learn the next topic. The utterance $(\mathrm{f})$ "it is pretty easy" was also delivered by the teacher to attract the students' interest, so they would be willing to answer other questions. The next sentence (g) "let's give applause!" happened when the group presenting in front of the class did the good job, so the teacher asked other students to give them applause as their reward.

Another example of positive politeness usage can be seen through the joke expressions such as in the sentence (h) "and the last one... me" in which this sentence occured when there was still one question left, so the teacher decided to answer it by himself. After the teacher said "and the last one... me", all students were laugh, so the class became more interesting than before. The other joke found in the teacher's talk was the expression (i) "if I tell you what it is you would say "oh, really! Its function is a hot water bag" used by the native English teacher to give clues about the answer for the students. In telling the clues, the teacher applied positive politeness strategy in the form of joke expression. As a result, all students in the class were laugh and they said "oooh my God!".

The use of positive politeness strategy performed by the native English teacher could create a good atmosphere among the teacher and the students in the class, such as a comfortable environment and pleasant classroom situation. Further, the native English teacher in this research always made jokes when the teaching and learning process was ongoing, so the students didn't feel bored even they enjoyed studying english in the class. This finding was in line with Nurmawati et al., (2019) who stated that positive politeness strategy was used by the teacher to give the students confidence to work without pressure, motivate the students to participate more in the class, and make students feel comfortable and free to interact in the classroom. 


\subsection{Negative Politeness}

Negative politeness refers to the negative face of the hearer. It is used to show the existence of social distance between the speaker and the hearer (Brown and Levinson, 1987). Negative politeness strategy was mostly applied by the native English teacher in order to request the students to do something and also give suggestions to them. It could be identified by the use of conventionally indirect expressions, such as:

a. "So, can you try it again?"

b. "Hafsoh, can you do me a favor and tell me what is the number 2?"

c. "Alif, Alif, number 21 please."

d. "Will you read the full sentence?"

e. "Can you guess that?"

f. "I suggest to be creative with your ingredients."

g. "I think you should use what you have."

h. "Oh, Rivo? What did you say? 'shhh', I hope you're supposed to say 'oh, great! I can go first'."

i. "Can you come a little forward? So you don't have to be on the back."

j. "Can you make sure you're engaging the audiences when you present?"

k. "You should glance the audience, not the paper."

l. "Can you tell us about number 26?"

The first expression (a) happened when the female student had mispronounced some vocabularies that appeared in the sentence being discussed. Hence, the teacher asked her to read the sentence once more by saying "so, can you try it again?" in order to make the student's pronounciation correct. The second sentence (b) occured when the teacher reviewed the students' assignment. The utterance 'Hafsoh, can you do me a favor and tell me what is the number 2?" was delivered by the teacher to request a student named Hafsoh to help him answer the question of number 2. Further, the use of the word please in sentence (c) "Alif, Alif, number 21 please" showed a respectability expressed by the teacher in order to ask the male student answer the question of number 21 . The other negative politeness strategy which was realized through the use of conventionally indirect expression was in the sentence (i) "can you come a little forward, so you don't have to be on the back?". This utterance passed when the students didn't sit in the front seats, but all of them sit on the back. Hence, the teacher requested the students to come a little forward, so that they didn't have to sit on the back seats.

Besides that, the suggestion form could also be seen as the clear examples of negative politeness strategy. The sentence (f) "I suggest to be creative with your ingredients" was uttered by the native English teacher to request the students more creative in making the recipe with the weird ingredients. The second expression of suggestion was (g) "I think you should use what you have" that occured when a male student asking to the teacher whether he could add another ingredients or not. In responding to the student's question, the native English teacher applied negative politeness strategy in the form of suggestion by saying "I think you should use what you have". It was in order to ask the student not to add the new ingredients and they should use the provided ingredients. The other expression was (k) "you should glance the 
audience, not the paper" that was conveyed by the teacher when there were still some students who didn't engange the audiences instead they looked at the paper. Thus, the teacher requested them to engage the audiences through the suggestion expression by saying "you should glance the audience, not the paper". It was in line with Peng et al., (2014) that many sentence patterns expressed by the teacher were suggestive in which it made the serious question-answer atmosphere less stressful, and the students had more freedom of choices.

Since the teacher's talks in the class mostly intended to request and command the students to do something, negative politeness strategy became the best choice to be applied in every speech. That was why negative politeness became the most dominant politeness strategy used by the native English teacher in the class. By means of negative politeness strategy in his talk to the students, it could minimize the imposition caused by the teacher's request in which the request expressions were considered FTA, so it risked to threaten the students' face (self-image) even it could make the students uncomfortable because their freedom of action was impeded. In addition, the use of negative politeness strategy could be used to soften the speaker's utterances, so that it would make the hearer not burdened in accomplishing the teacher's request. As said by Djatmika et al., (2016) that negative politeness suggested that no one wanted to be burdened, they tried to be indirect in giving the commands and to minimize the imposition.

\subsection{Off Record}

Off-record strategy is considered as an attempt by the speaker to remove themselves from any imposition. The speaker could apply off record strategy when he wants to do the FTA, but wants to avoid the responsibility for doing it (Brown and Levinson, 1987). It is usually employed by using indirect speech and also giving hints to the addressee, so it will leave it up to the addressee to interpret the meaning by himself. Off-record strategy was rarely used by the native English teacher in this research. There were only six utterances expressed by using off-record strategy, for instances:

a. "What language is it? Which language is it?"

b. "The full sentence."

c. "So? [Pointing at the female student]"

The first sentence (a) came about as a male student used Bahasa Indonesia when talking to his friends in speaking class. Thus, the teacher reminded him through an indirect speech by pretending to ask a question "what language is it? which language is it?". In this context, the teacher didn't actually want to ask about what the language used by that student. However, he would like to remind the student to use English in speaking class by giving him the association clue. In responding the teacher's question, the student immediately apologized to his teacher, then he changed his language from Bahasa Indonesia into English. It means that the male student could interpret the teacher's intention, although his teacher didn't state the speech directly. The second expression (b) "the full sentence" transpired while the students didn't read the sentence completely. Therefore, the teacher indirectly requested them 
to read the full sentence by saying "the full sentence". In this atmosphere, the teacher realized off-record strategy by using incomplete sentence (ellipsis) through a declarative form. Then, the last expression of off record usage was a simple sentence of "so?". It went on after the teacher told the pronounciation of a word, then the students repeated the pronounciation. The ellipsis of "so?" here was not just a simple question, but it was actually used by the teacher to request the students repeat the pronounciation of the word anymore.

Off-record strategy in this research was least used by the teacher in his talk, because it needed an effort to interpret the meaning in understanding the speaker's intention. In addition, it was rarely employed due to the difficult interpretation. It meant that when the speaker decided to apply off-record strategy, he left it up to the hearer to interpret the meaning by himself. As a result, sometimes, the hearer misunderstood when interpreting the speaker's meaning for the hearer couldn't comprehend the message.

\section{Conclusion}

This study is conducted to identify politeness strategies used by the native English teacher in EFL classroom interaction. The result shows that the native English teacher realizes all politeness strategies, namely bald on record, positive politeness, negative politeness, and off record. Bald on record is used by the teacher when he wants to remind (warn) the students and give them commands, especially for task-oriented. Positive politeness is applied when the teacher gives compliments to the students (showing appreciation), creates the atmosphere of the class more interesting, and encourages the students' motivation. Negative politeness is mostly performed by the teacher in order to request the students to do something and give advices to them. Last, off-record is employed by the teacher in reminding and commanding the students in indirect way. Through the result of the research, it can be concluded that the idea of politeness theory suggested by Brown and Levinson (1987) is applicable in language teaching and learning process in the class, especially in Indonesia classroom context.

\section{References}

Agustina, S., \& Cahyono, Bambang Y. (2016). Politeness and power relation in EFL classroom interactions: A study on Indonesian learners and lecturers. International Journal of Language and linguistics, 3 (2).

Brown, Penelope \& Levinson, Stephen C. (1987). Politeness: Some universals in language use. Cambridge: Cambridge University Press.

Creswell, John W. (2007). Qualitative inquiry and research design: Choosing among five approaches. California: SAGE Publications, Inc.

Djatmika, et.al. (2016). Politeness strategies performed by teachers to effectively assist children with autism in their learning process. Humaniora, vol. 28, 28-36.

Grice, H.P. (1975). Logic and conversation. In Cole and Morgan, eds., 41-58. Repr. in Grice, 1989, 213-233. 
Kasper, G \& Blum-Kulka, S. (1993). Interlanguage pragmatics. New York: Oxford University Press.

Lakoff, R.T. (1990). Talking power: The politics of language in our lives. Glasgow: HarperCollins.

Manik, Sondang \& Hutagaol, Juniati. (2015). An analysis on teachers' politeness strategy and student's compliance in teaching learning process at SD Negeri 024184 Binjai Timur - North Sumatra - Indonesia. English Language Teaching Journal, 8 (8).

Miles, Matthew B., Hubberman A. Michael., \& Saldana, Johnny. (2014). Qualitative data analysis: A methods sourcebook. United States of America: SAGE Publications, Inc.

Nashruddin, et.al. (2018). Politeness principle and its implication in EFL clasroom in Indonesia. XLinguae, 11 (4).

Nurmawati, et.al. (2019). An analysis of positive politeness strategies to promote effective interaction in the classroom. ELS Journal on Interdisciplinary Studies in Humanities, 2 (2), 171-181.

Peng, et.al. (2014). A case study of college teacher's politeness strategy in EFL classroom. Theory and Practice in Language Studies, 4(1), 110-115. Academy Publisher: Finland.

Rose, Kenneth R \& Kasper, Gabriele. (2001). Pragmatics in language teaching. Cambridge

Senowarsito. (2013). Politeness strategies in teacher-student interaction in an EFL classroom context. TEFLIN Journal, 24 (1).

Yuni Elisdawati, Rahmad Husein, and Eddy Setia. (2018). Teachers' politeness strategies in motivating students to learn english. The 1st Annual International Conference on Language and Literature, KnE Social Sciences, pages 964-975. DOI 10.18502/kss.v3i4.2004 